\title{
Prior Activation of Kappa Opioid Receptors by U50,488 Mimics Repeated Forced Swim Stress to Potentiate Cocaine Place Preference Conditioning
}

\author{
Jay P McLaughlin',4, Benjamin B Land ${ }^{1,2}$, Shuang Li', John E Pintar ${ }^{3}$ and Charles Chavkin*,1,2 \\ 'Department of Pharmacology, University of Washington School of Medicine, Seattle, WA, USA; ${ }^{2}$ Program in Neurobiology and Behavior, \\ University of Washington School of Medicine, Seattle, WA, USA; ${ }^{3}$ Department of Neuroscience and Cell Biology, UMDNJ, Robert Wood Johnson \\ Medical School, Piscataway, NJ, USA
}

\begin{abstract}
Repeated forced-swim stress (FSS) produced analgesia, immobility and potentiation of cocaine-conditioned place preference (CPP) in wild-type C57BI/6 mice, but not in littermates lacking the kappa opioid receptor (KOR) gene. These results were surprising because kappa agonists are known to produce conditioned place aversion and to suppress cocaine-CPP when coadministered with cocaine. The possibility that disruption of the kappa system blocked the stress response by adversely affecting the hypothalamic-pituitary axis was examined by measuring plasma corticosterone levels. However, disruption of the dynorphin/kappa system by gene deletion or receptor antagonism did not reduce the FSS-induced elevation of plasma corticosterone levels. A second explanation for the difference is that kappa receptor activation caused by FSS occurred prior to cocaine conditioning rather than contemporaneously. To test this hypothesis, we measured the effects of the kappa agonist (trans)-3,4-dichloro-N-methyl-N-[2-( I-pyrrolidinyl)-cyclohexyl]benzeneacetamide $(\cup 50,488)$ administered to mice at various intervals preceding cocaine conditioning. The results showed that the interaction between the kappa system and cocaine reinforcement depended on the timing of the drug pairing. Mice given U50,488 60 min prior to cocaine showed a robust, nor-BNI-sensitive potentiation of cocaine-CPP, whereas administration 15 min before cocaine significantly suppressed cocaine-CPP. In the absence of cocaine, U50,488 given 60 min prior to saline conditioning produced no place preference, whereas administration 15 min before saline conditioning produced significant place aversion. The results of this study suggest that kappa receptor activation induced by FSS prior to the cocaine-conditioning session may be both necessary and sufficient for potentiation of the reinforcing actions of cocaine.

Neuropsychopharmacology (2006) 31, 787-794. doi:I0.1038/sj.npp. I300860; published online 10 August 2005
\end{abstract}

Keywords: kappa; opioid; dynorphin; stress; depression; cocaine; conditioned place preference; aversion

\section{INTRODUCTION}

In a previous study, we found that repeated forced-swim stress (FSS) dramatically increased the reinforcing effects of cocaine by a mechanism that required kappa opioid receptor (KOR) activation (McLaughlin et al, 2003). Repeated forced swim in warm $\left(30^{\circ} \mathrm{C}\right)$ water preceding cocaine place preference conditioning resulted in a near doubling of the time spent in the drug-paired compartment during the subsequent preference test as compared to

\footnotetext{
*Correspondence: Dr C Chavkin, Department of Pharmacology, University of Washington, Box 357280, Seattle, WA 98195-7280, USA, Tel: + I 206543 4266, Fax: + I 2066853822 ,

E-mail: cchavkin@u.washington.edu

${ }^{4}$ Present address: Department of Psychology, Northeastern University, Boston, MA 02115 , USA

Received 20 April 2005; revised and accepted 29 June 2005

Online publication: 6 July 2005 at http://www.acnp.org/citations/ Npp07060505026//default.pdf
}

unstressed mice. The increase in preference was blocked by either pretreatment with the kappa opioid antagonist norbinaltorphimine (nor-BNI) prior to conditioning or deletion of the gene for the endogenous kappa opioid peptide dynorphin (DYN). These results suggested that activation of the endogenous kappa opioid system changed the way that mice responded to the reinforcing effects of cocaine, although alternative explanations remain and the underlying mechanisms are not yet known.

Prior studies had established that stress potentiates the rewarding properties of drugs of abuse (Piazza et al, 1990; Will et al, 1998; Covington and Miczek, 2001; Haile et al, 2001), but a facilitating role of the kappa opioid system was surprising as kappa agonists are known to block the reinforcing effects of cocaine (Suzuki et al, 1992; Maisonneuve et al, 1994; Zhang et al, 2004). In addition, kappa opioid agonists produce conditioned place aversion in rodents (Shippenberg and Herz, 1986; Suzuki et al, 1992), and produce dysphoria in humans (Pfeiffer et al, 1986). 
Based on those data, it was reasonable to expect that the stress-induced activation of the endogenous DYN/kappa system would serve as a brake that would reduce the reinforcing effects of cocaine.

However, key differences between the experimental protocols could have been responsible for the apparently conflicting results. Specifically, the actions of endogenous DYNs released by stress may be different from those produced by the pharmacological activation of kappa receptors. First, to establish the involvement of the KOR in the stress-induced potentiation of cocaine conditioned place preference (CPP), the effects of KOR gene deletion were assessed. This was important because nor-BNI and proDYN-derived peptides potentially have alternative sites of action. Second, to determine if the stress experience and subsequent release of other stress hormones was required, we simplified the paradigm by injecting the kappa agonist (trans)-3,4-dichloro- $N$-methyl- $N$-[2-(1-pyrrolidinyl)-cyclohexyl]benzeneacetamide (U50,488) prior to the cocaineconditioning session. To match the timing and magnitude of the endogenous kappa peptide action, we compared different intervals between U50,488 and cocaine injections, and we chose a dose of drug that produced the same magnitude of analgesic effects as the DYN-mediated stressinduced analgesia (SIA). Prior results suggested that kappa receptor activation was necessary for stress-induced potentiation of the cocaine-CPP. The present study addresses whether kappa receptor activation by administration of a kappa drug in the absence of FSS was sufficient.

\section{MATERIALS AND METHODS}

\section{Animals and Housing}

Male C57Bl/6 mice (Charles River Laboratories, Wilmington, MA) weighing 22-32 g (12-16 weeks old) were used in these experiments. Mice were group-housed, 2-4 per cage, in self-standing plastic cages $(28 \mathrm{~cm} \mathrm{~L} \times 16 \mathrm{~cm} \mathrm{~W} \times 13 \mathrm{~cm}$ $\mathrm{H})$ using 'Bed-o-Cob' for home bedding within the animal core facility at the University of Washington, and maintained in a specific pathogen-free housing unit. Mice were transferred 1 week prior to training into a colony room adjacent to the testing room to acclimatize to the testing environment. Housing rooms were illuminated on a $12-\mathrm{h}$ light-dark cycle with lights on at 0700 . Food pellets and water were available ad libitum. Procedures with mice were approved by the institutional Animal Care and Use Committee in accordance with the 1996 NIH Guide for the Care and Use of Laboratory Animals, and mice were inspected regularly by veterinary staff to ensure compliance.

\section{Breeding and Genotyping of 'Knockout' Mice}

Homozygous KOR and prodynorphin knockout $(-/-)$ mice were prepared by homologous recombination as described (Hough et al, 2000; Sharifi et al, 2001) and provided for this study. Animals were backcrossed for $>10$ generations with C57Bl/6 mice, and heterozygote breeding pairs were used to generate homozygotic 'knockout' mice of each type and paired wild-type (WT) littermate controls for this study. Individual mice were genotyped using DNA extracted from tail samples as a PCR template as described previously
(McLaughlin et al, 2003; Terman et al, 2004; Xu et al, 2004). The prodynorphin and KOR gene-disrupted animals show no discernible differences from WT littermates in growth, life span, or overt behavior.

\section{Corticosterone Assay}

Mouse serum corticosterone levels were determined by $\left[{ }^{3} \mathrm{H}\right]$ radioimmunoassay, following the manufacturer's protocol (MP Biomedicals, Orangeburg, NY). Trunk blood was collected following decapitation.

\section{Forced-Swim Stress}

To induce stress, $\mathrm{C} 57 \mathrm{Bl} / 6$ mice were exposed to a modified forced-swim test as previously described (McLaughlin et al, 2003). Briefly, the modified-Porsolt forced-swim paradigm (Porsolt et al, 1977) used was a 2-day procedure in which mice swam in $30^{\circ} \mathrm{C}$ water for $15 \mathrm{~min}$ the first day, then $6 \mathrm{~min}$ during each of four trials on the second day without the opportunity to escape. Time spent immobile during the last 4 min of each trial was recorded. Difficulties in swimming or staying afloat were criteria for exclusion; however, no mice met these criteria.

\section{Antinociceptive Testing Using the $55^{\circ} \mathrm{C}$ Warm-Water Tail-Withdrawal Assay}

The response latency for the mouse to withdraw its tail following immersion in $55^{\circ} \mathrm{C}$ water was taken as the end point (Vaught and Takemori, 1979), modified as previously described (McLaughlin et al, 2003). A cutoff time of $15 \mathrm{~s}$ was used to prevent tissue damage.

\section{Conditioned Place Preference}

KOR $(-/-)$ and WT littermate C57Bl/6 mice were used in a three-compartment place-conditioning apparatus as described previously (McLaughlin et al, 2003). Mice were tested for place preference by placing individual animals in the small central compartment and allowing them to freely explore the entire apparatus for $30 \mathrm{~min}$. Movement through the chambers was detected by the breaking of infrared beams emitted from imbedded sensors, recorded by an automated computerized system (LabLinc, Coulbourn Instruments, Allentown, PA). Time spent in the two outer compartments was then calculated by GraphicState2 software (Coulbourn Instruments, Allentown, PA).

To examine the effect of FSS on cocaine-CPP, mice were tested for preconditioning bias, then exposed to 2 days of vehicle or nor-BNI $(10 \mathrm{mg} / \mathrm{kg}$ i.p./day) pretreatment and forced swim as described above. This dose of nor-BNI was shown previously to be kappa selective under these testing conditions (McLaughlin et al, 2003). At $10 \mathrm{~min}$ after the second day forced-swim session, mice were injected with cocaine $(15 \mathrm{mg} / \mathrm{kg}$, s.c.) and placed in the drug-paired compartment for $30 \mathrm{~min}$ to begin conditioning as described previously (McLaughlin et al, 2003). After $4 \mathrm{~h}$, animals were injected with saline and confined to the nondrug-paired compartment of the conditioning apparatus. Cocaine and saline conditioning were repeated in the same chambers on day 3 such that mice received 2 days of 
cocaine conditioning. The experiment concluded on day 4 with testing of CPP. Alternatively, mice received daily U50,488 (5 mg/kg i.p.) pretreatment in lieu of exposure to FSS. In these experiments, mice were injected with cocaine at various times $15-360 \mathrm{~min}$ after U50,488 administration, and placed in the cocaine-paired compartment for $30 \mathrm{~min}$ to begin conditioning. Note that results are plotted as the difference in the times spent on the cocaine-paired side $v s$ the vehicle-paired side. Therefore, a positive value demonstrates preference for the cocaine-paired side. The testing apparatus is balanced; animals conditioned with saline in both compartments develop no significant chamber preference (McLaughlin et al, 2003).

This study utilized a three-chambered preference test apparatus, and thus needed to consider whether time spent in the central compartment was affected by the treatments tested. Analysis of time spent in the time spent in the central compartment before and after cocaine conditioning showed no significant effects of genotype, prior drug exposure or prior stress exposure. Prior to cocaine conditioning, mice spent approximately $570 \mathrm{~s}$ in the central compartment $(\mathrm{KOR}(+/+)$ mice, $581 \pm 18.7 \mathrm{~s}(n=50)$; $\operatorname{KOR}(-/-)$ mice, $588 \pm 23.4 \mathrm{~s}(n=44), \mathrm{WT}$ C57Bl/ 6 mice, $548 \pm 13.3 \mathrm{~s}$, $n=124)$. Pretreatment with either saline, nor-BNI, U50,488 or swim stress prior to cocaine conditioning had no significant effect on time spent in the central compartment during the subsequent preference test (data not shown).

\section{Data Analysis}

Behavioral data were analyzed by analysis of variance (oneway or two-way ANOVA). Significant results demonstrated by ANOVA were further analyzed for significance with the Fisher's or Neuman-Keuls post hoc tests for significant pairwise comparisons. Dependent variables were expressed as the time spent immobile during forced swimming in all FSS experiments, and the latency of time spent before removing the tail in the tail-withdrawal tests. Comparisons were analyzed for swim-stressed groups receiving nor-BNI or vehicle pretreatment, with the additional factors of WT, KOR gene disruption. CPP experiments express the dependent variable as the difference in time spent in the drug- and saline-paired compartments. Data for CPP groups were analyzed for cocaine or vehicle conditioning, with the additional factors of swim-stressed $v s$ unstressed groups, nor-BNI or vehicle pretreatment and WT or KOR gene disruption. Analysis compared differences in time spent in the (eventual) drug- and saline-paired compartments, before and after FSS exposure. Seconds spent in the drug-paired, saline-paired, and neutral zone compartments were additionally analyzed separately. Data are presented as means $\pm S E M$ of the animal treatment group, with significance set at $P<0.05$.

\section{RESULTS}

\section{Stress-Induced Responses were Disrupted by KOR Gene Deletion}

The hypothesis that stress-induced release of endogenous DYNs activates KORs is based on the receptor specificity of the antagonist nor-BNI and assumptions about the selective effects of proDYN gene disruption (McLaughlin et al, 2003). ProDYN-derived opioids might also act at non-kappa receptors (Chavkin and Goldstein, 1981; Young et al, 1986). To test the hypothesis, SIA, immobility, and cocaine-CPP potentiation were assessed in $\operatorname{KOR}(-/-)$ and WT littermates exposed to repeated FSS. Consistent with previous results, WT mice showed significant increases in tail-withdrawal latency when analyzed by two-way ANOVA [factor swim + factor Kappa] $\left(F_{\text {Swim } / 1,136}=15.07, P<0.001\right.$; $F_{\text {Kappa/5,136 }}=17.41, \quad P<0.001 ; \quad F_{\text {Swim } \times \text { Kappa } / 3,136}=14.95$, $P<0.001)$. As evident in Figure 1a, KOR $(-I-)$ mice did not show significant analgesia following repeated forcedswim. WT-stressed mice showed significant increases in tail-withdrawal latency when compared to unstressed mice $(P<0.05$, Newman-Keuls Multiple-comparison post hoc
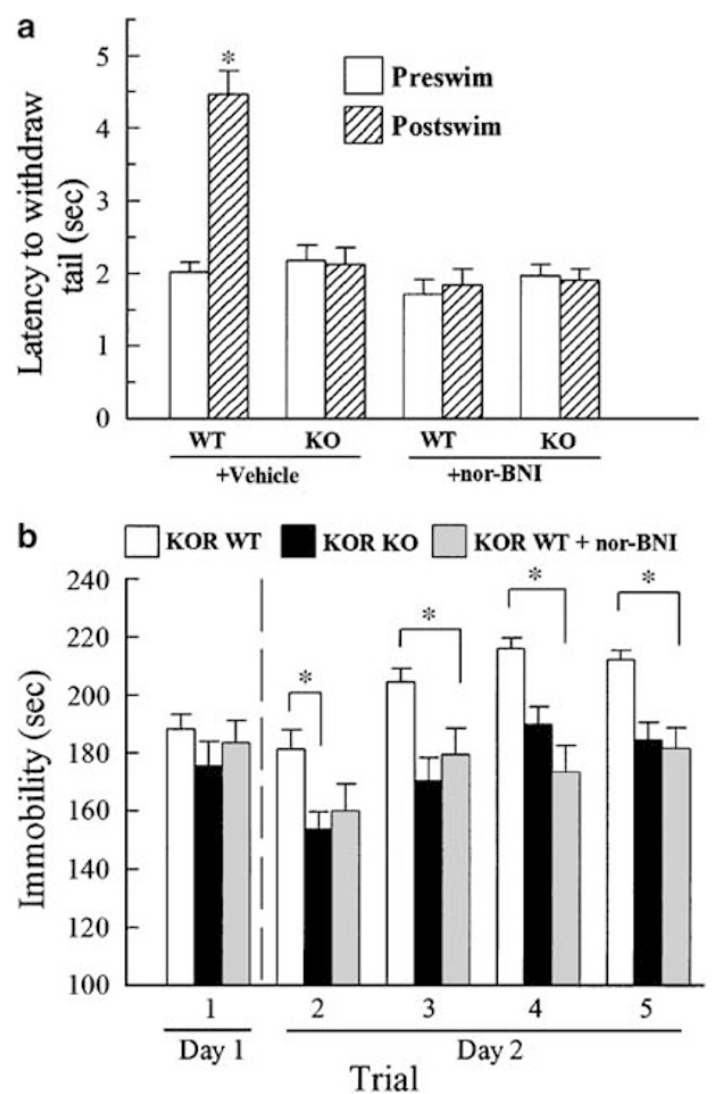

Figure I FSS-induced analgesia and immobility is reduced on the second day of testing by pretreatment with nor-BNI or by disruption of the kappa opioid receptor (KOR) gene. (a) Tail withdrawal latencies in the $55^{\circ} \mathrm{C}$ warm-water assay presented were obtained 5-9 min after forced swim on the second day. $*$ = Significantly different than matching preswim latencies, $P<0.05$, as determined by two-way ANOVA followed by Newman-Keuls Multiple-Comparison post-hoc test. (b). The time mice spent immobile during the last $4 \mathrm{~min}$ of the forced swim test was measured during multiple trials over 2 days. $(P<0.05$, Figure I b, trials $3-5)$. KOR WT mice received either vehicle (open bars) or nor-BNI ( $10 \mathrm{mg} / \mathrm{kg}$, i.p., grey bars) in a bolus of $0.3 \mathrm{ml} / 30 \mathrm{~g}$ body $\mathrm{wt}$ I $\mathrm{h}$ prior to daily swimming. KOR $(-/-)$ mice received vehicle (black bars) on the same protocol and schedule. $*=$ significant difference between immobility responses of stress-exposed vehicle-treated and nor-BNI treated WT mice or between immobility responses of WT and KOR gene disrupted mice, $P<0.05$, as determined by one-way ANOVA followed by Newman-Keuls Multiple-comparison post hoc test. Bars represent $n=16-22$ animals in both (a and b). 
test). The increases were blocked by either nor-BNI pretreatment or disruption of the KOR gene. There were no differences between unstressed mice and stressed norBNI pretreated mice or stressed KOR knockout mice $(P>0.05$, Newman-Keuls Multiple-comparison post hoc test). Similar to nor-BNI treated WT mice, KOR $(-/-)$ mice did not develop stress-induced immobility following FSS (Figure 1b). Neither nor-BNI pretreatment nor KOR gene deletion significantly affected time spent immobile on the first day of testing (Figure $1 \mathrm{~b}$, trial $1 ; F_{2,53}=0.83$, $P>0.05$, one-way ANOVA). However, on the second day of forced-swim KOR knockout significantly reduced the time spent immobile in the first trial of the day (the second swim trial overall) as compared to the time of the vehicle-treated set (Figure 1b, trial 2, one-way ANOVA $F_{2,53}=4.29$, $P<0.05)$. Overall, both KOR knockout and nor-BNI pretreatment of WT mice significantly reduced the immobility and analgesia induced by FSS.

WT and KOR $(-/-)$ littermate mice developed equivalent cocaine-CPP in the absence of stress (Figure 2). In contrast, KOR (-I-) mice exposed to FSS prior to cocaine conditioning produced a cocaine-CPP response that was not significantly different from that of unstressed KOR $(+I+)$ or $(-I-)$ mice (Figure 2$)$. WT mice exposed to FSS prior to cocaine conditioning demonstrated a significant, two-fold greater place preference over that shown by unstressed or nor-BNI pretreated, stressed mice $\left(F_{2,55}=\right.$ 5.76, $P<0.05$; one-way ANOVA followed by NeumanKeuls Multiple-comparison post hoc test). In contrast, vehicle-treated KOR knockout mice exposed to FSS did not $\left(F_{2,41}=0.31, P>0.05\right.$; one-way ANOVA followed by Neuman-Keuls Multiple-comparison post hoc test). To

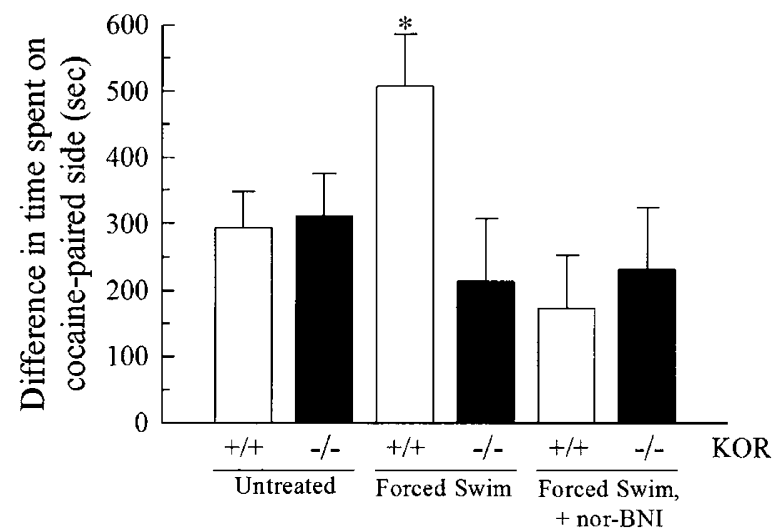

Figure 2 Exposure to FSS results in a KOR-mediated potentiation of cocaine conditioned place preference. WT and KOR (-I-) mice were divided into three groups each. The first group was unstressed, remaining in home cages prior to 2 days of cocaine and saline conditioning (left pair). The remaining groups were administered either vehicle (center pair) or nor-BNI ( $10 \mathrm{mg} / \mathrm{kg}$, i.p., right pair) in a bolus of $0.3 \mathrm{ml} / 30 \mathrm{~g}$ body wt I h before repeated FSS and then conditioned over 2 days with cocaine and saline as previously described (McLaughlin et al, 2003). Subsequent preference results collected blind are plotted in seconds to highlight time spent on the drug-paired side of the apparatus. $Y$-axis values represent the difference in time spent in the cocaine-paired compartment subtracted from the saline-paired side on test day. ${ }^{*}=$ significant difference in cocaineCPP compared with CPP for both unstressed and nor-BNI-treated mice. $P<0.05$, as determined by one-way ANOVA followed by Newman-Keuls Multiple-comparison post hoc test. (Bars represent $n=12-22$ mice). verify that the KOR $(-/-)$ response was not the result of genetic compensation, WT and $\mathrm{KOR}(-I-)$ were pretreated with nor-BNI and exposed to FSS prior to cocaine-CPP testing. Nor-BNI $(10 \mathrm{mg} / \mathrm{kg})$ pretreatment of FSS-exposed $\operatorname{KOR}(+/+)$ mice prevented the potentiation of the cocaine-CPP response; their response was not significantly different from the response produced by the unstressed $\operatorname{KOR}(+/+)$ mice (Figure 2). Swim-stressed, nor-BNI pretreated KOR $(-/-)$ mice demonstrated cocaine-CPP responses that were not significantly different from the responses produced by the unstressed or vehicle-pretreated swim-stressed mice (Figure 2). Thus, while disruption of the KOR gene did not alter the basic cocaine-CPP response, it did prevent the stress-induced potentiation of cocaine-CPP. These results strengthen the hypothesis that stress-induced release of endogenous prodynorphin-derived opioids can produce analgesia, immobility, and potentiation of cocaineCPP by a KOR-mediated mechanism.

\section{KOR Activation is Sufficient for Potentiation of Cocaine-CPP}

Swim stress induces a complex physiological response that might contribute to the enhanced CPP. For example, serum corticosterone levels in WT mice subjected to FSS increased three-fold (Figure 3), an expected response to stress in this strain of mouse (Hotchkiss et al, 2004). Importantly, treatments able to block stress-induced potentiation of cocaine-CPP did not affect the FSS-induced elevation of corticosterone. FSS increased serum corticosterone levels three-fold in WT mice pretreated with nor-BNI and in prodynorphin $(-/-)$ mice pretreated with either vehicle or nor-BNI (Figure 3). These increased levels were not significantly different from the response of WT mice. The results suggest that the block in potentiation of cocaine-CPP

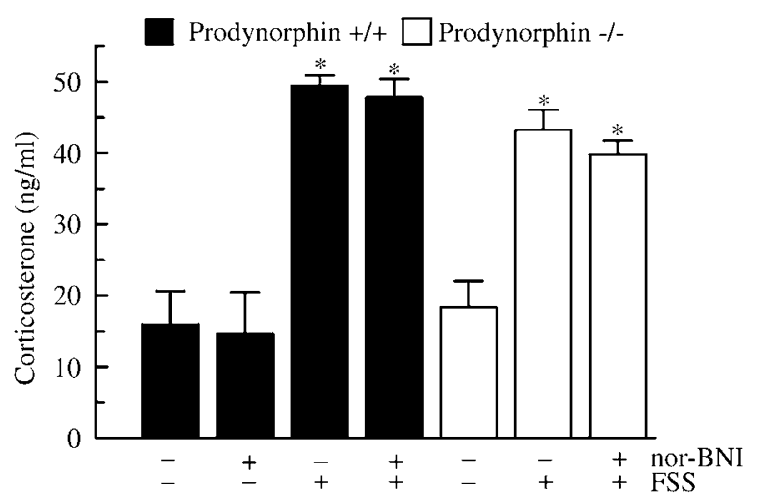

Figure 3 Stress-induced increases in corticosterone do not account for potentiation of cocaine conditioned place preference. Serum corticosterone levels in WT mice subjected to FSS increased three-fold (from a baseline of $16.0 \pm 4.70 \mathrm{ng} / \mathrm{ml}, n=\mid$ | to $49.5 \pm 1.470 \mathrm{ng} / \mathrm{ml}, n=8)$. Notably, both WT mice pretreated with nor-BNI and prodynorphin (-/-) mice showed a normal three-fold increase in serum corticosterone levels not significantly different from the response of WT mice, although both of these treatments prevented stress-induced potentiation of cocaineconditioned place preference. Statistical comparisons were carried out for DYN, WT, and -/- mice separately to define effects of nor-BNI and swim stress. $* P<0.05$ compared with untreated control as determined by one-way ANOVA followed by Newman-Keuls Multiple-comparison post hoc test. (Bars represent $n=8-1$ I mice). 
was not caused by gross disruption of the hypothalamicpituitary-adrenal axis (HPA) function and suggest that kappa system disruption alone might be sufficient.

To test the hypothesis that direct activation of KOR in the absence of repeated swim stress would result in the potentiation of the cocaine-CPP response, mice were administered the selective kappa agonist U50,488 prior to cocaine conditioning. To mimic the degree of kappa receptor activation produced by the forced swim, a U50,488 dose-response curve was first generated using the $55^{\circ} \mathrm{C}$ warm-water tail-withdrawal assay (Figure 4). Administration of U50,488 at $5 \mathrm{mg} / \mathrm{kg}$ produced a $5.4 \pm 0.47 \mathrm{~s}$ response latency, which was not significantly different from the response latency of $4.5 \pm 0.33 \mathrm{~s}$ shown by WT mice exposed to FSS (Figure 1a). To determine the effect of prior kappa receptor activation as produced by forced swim, unstressed mice were administered U50,488 $(5 \mathrm{mg} / \mathrm{kg})$ or saline at various times up to $6 \mathrm{~h}$ before or $30 \mathrm{~min}$ after cocaine conditioning (as illustrated in Figure 5a).

As evident in Figure 5b, the magnitude of the subsequent cocaine-CPP response was dependent on the interval between U50,488 and cocaine administration. Kappa receptor activation $6 \mathrm{~h}$ before cocaine conditioning did not significantly affect the cocaine-CPP $(P>0.05)$, whereas U50,488 treatment 60 min before cocaine produced a robust potentiation of the resulting CPP compared with salinepretreated mice $\left(F_{5,115}=4.71, P<0.001\right.$; one-way ANOVA, followed by Fisher's LSD Multiple-comparison post hoc test Figure 5b). The magnitude of potentiation $(625 \pm 110 \mathrm{~s}$ preference) was equivalent to that produced by FSS. The potentiation produced by U50,488 was blocked by pretreatment with nor-BNI $(10 \mathrm{mg} / \mathrm{kg})$; mice administered nor-BNI and U50,488 $60 \mathrm{~min}$ prior to cocaine conditioning showed a subsequent cocaine-CPP response of $298 \pm 73 \mathrm{~s}$, a value that was not significantly different from the normal cocaine-CPP response in the absence of stress or U50,488 $(P>0.05$, Student's $t$-test). Note that the timing of the nor-BNI

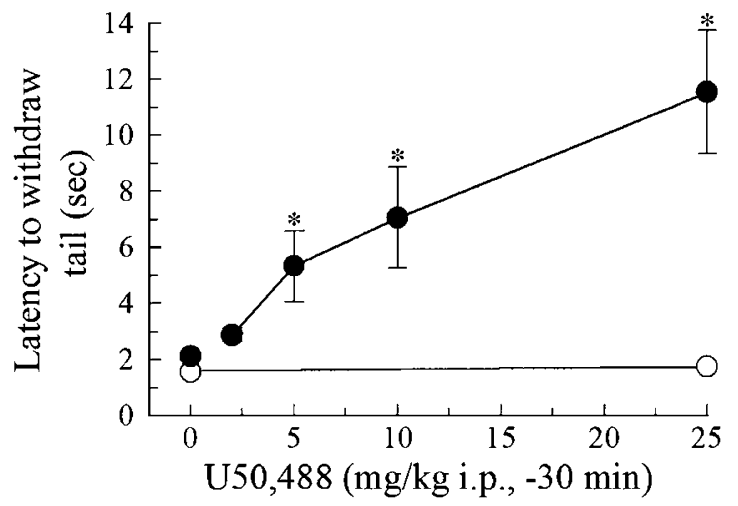

Figure 4 Dose-response of U50,488-induced antinociception in the mouse $55^{\circ} \mathrm{C}$ warm-water tail withdrawal assay. Response latencies were obtained both before and $30 \mathrm{~min}$ after C57BI/6 mice (dark circles) were injected with a single dose of $\cup 50,488$ (2, 5, 10 , or $25 \mathrm{mg} / \mathrm{kg}$ i.p.). Similarly, tail withdrawal latencies were obtained both before and $30 \mathrm{~min}$ after $\mathrm{KOR}$ $(-/-)$ mice (open circles) were injected with U50,488 (25 mg/kg i.p.). Circles represent $n=6-9$ mice (WT) or $n=24$ mice (KOR knockout). $*$ = significantly different than vehicle-treated mice, $P<0.05$, as determined by one-way ANOVA followed by Fisher's LSD Multiple-comparison post hoc test.

\section{\begin{tabular}{l|l|l|l} 
a Day: 1 & 2 & 3 & 4 \\
\hline $\mathbf{\Delta}$ & $\diamond$ & $\mathbf{2}$ & $\diamond$
\end{tabular}}

$\boldsymbol{\Delta}$ Preference test, $30 \mathrm{~min} \diamond \mathrm{U} 50,488(5 \mathrm{mg} / \mathrm{kg}$ i.p.) or saline

Cocaine (Fig. b) or vehicle (Fig. c) conditioning, $30 \mathrm{~min}$ Vehicle conditioning, $30 \mathrm{~min}$

b

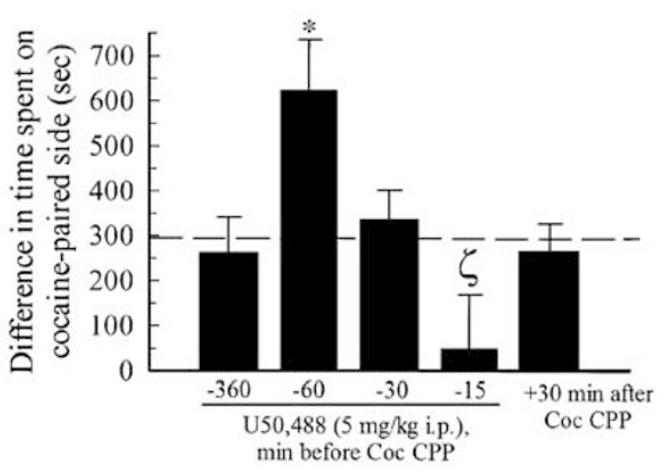

C

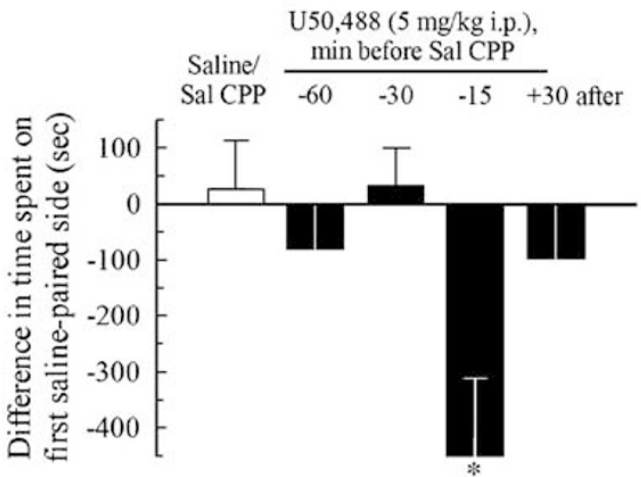

Figure 5 Pretreatment with KOR agonist is sufficient to produce a timedependent potentiation or suppression of cocaine conditioned place preference. (a). Schematic of training paradigm. Preference testing allowed mice to move freely for 30 min between the three chambers (triangles). Mice were pretreated on day 2 with vehicle or $U 50,488(5 \mathrm{mg} / \mathrm{kg}$, i.p.; diamonds) at a time ranging from $6 \mathrm{~h}$ before to $30 \mathrm{~min}$ after administration of cocaine ( $15 \mathrm{mg} / \mathrm{kg}$, s.c.) then confined to the drug-paired box for a 30 min conditioning session (squares, referring to b). Mice used in conditioned place aversion studies (c) received saline instead of cocaine. After $4 \mathrm{~h}$, mice were given vehicle and confined to the vehicle-paired box for a 30-min conditioning session (circles). Drug pretreatment and conditioning were repeated the next day, separated again by $4 \mathrm{~h}$ (represented by the diamond and joined square and circle icons, day 3). On day 4, the final preference test was performed blind to determine the effect of treatment and conditioning on place preference. (b). Preference test data demonstrates a time-dependent activation of the KOR-induced potentiation of cocaine-CPP. * $=$ Significantly greater difference in cocaine-CPP compared with CPP for saline-pretreated mice; $\zeta=$ significantly less difference in cocaine-CPP compared with CPP for saline-pretreated mice, $P<0.05$, as determined by one-way ANOVA followed by Newman-Keuls Multiplecomparison post hoc test. (Bars represent $n=12-36$ mice). (c) Preference test data identifies a matching time course for conditioned place aversion induced by $U 50,488$. These experiments replaced cocaine with saline as detailed above in (a); preferences are given as the difference between time spent in the first-saline-paired chamber and time spent in the second-salinepaired chamber during the 30-min trial. A positive value represents the time spent in the first-saline-paired chamber. Treatment of mice with U50,488 $30 \mathrm{~min}$ after initial injection (and conditioning) with saline did not produce a significant preference or aversion for either chamber. * = significant difference in saline-CPP response compared with CPP for saline-pretreated mice, $P<0.05$, as determined by one-way ANOVA followed by Newman-Keuls Multiple-comparison post hoc test. (Bars represent $n=8-12$ mice). 
antagonism was also important. Mice given U50,488 60 min before cocaine conditioning and then treated with nor-BNI $1 \mathrm{~h}$ prior to final preference testing demonstrated a place preference $(505 \pm 49 \mathrm{~s})$ that was not significantly different from U50,488/cocaine-trained mice not given nor-BNI. Thus, nor-BNI needed to be administered prior to U50,488, which is consistent with simple competitive antagonism rather than a nonselective effect on performance.

When the interval between U50,488 and cocaine conditioning was reduced further, potentiation was not evident (Figure 5b). Mice given U50,488 $30 \mathrm{~min}$ prior to cocaine showed no significant potentiation of cocaine-CPP, and mice given $\mathrm{U} 50,48815 \mathrm{~min}$ prior to cocaine conditioning demonstrated a significant decrease in the postconditioning time spent in the cocaine-paired chamber $(49 \pm 121 \mathrm{~s})$ as compared to the saline-pretreated control $(P<0.05$; Fisher's LSD Multiple-comparison post hoc test). The KOR-mediated suppression of cocaine-CPP is consistent with the known aversive effects of kappa receptor stimulation (Suzuki et al, 1992), and these aversive effects were further demonstrated in the present study by measuring the place preference of mice given U50,488 in the absence of cocaine (Figure $5 \mathrm{c}$ ). In this experiment, mice were trained with saline in both compartments and received $5 \mathrm{mg} / \mathrm{kg} \mathrm{U} 50,488$ at various times prior to conditioning in the 'drug-paired' compartment (ie, the first saline-paired compartment). Mice given U50,488 at 60 or 30 min prior to CPP training developed no significant preference, whereas mice given U50,488 $15 \mathrm{~min}$ prior to training developed a significant conditioned place aversion $\left(-445 \pm 136 \mathrm{~s}, n=12, F_{4,46}=3.95, P<0.01\right.$; oneway ANOVA, followed by Fisher's LSD Multiple-comparison post hoc test; Figure 5c).

Mice given U50,488 immediately after cocaine conditioning showed neither potentiation nor suppression of cocaineCPP (Figure 5b). These results support the conclusion that the timing interval between prior kappa receptor activation and cocaine administration was critical, and the interval controlled the nature of the CPP response. Interestingly, analysis of the pharmacokinetics of U50,488 action $(5 \mathrm{mg} / \mathrm{kg}$ i.p.) showed that the analgesic effects peak at $30 \mathrm{~min}$ after injection and were gone by $60 \mathrm{~min}$ (data not shown). Thus by $60 \mathrm{~min}$, the majority of the acute response to U50,488 was likely to have dissipated prior to cocaine conditioning when the maximal potentiation of cocaine-CPP was observed.

\section{DISCUSSION}

The principal findings of this study are that: (1) repeated swim-stress resulted in immobility, analgesia and potentiation of cocaine-CPP that were blocked by KOR gene disruption; (2) kappa agonist administration both suppressed and potentiated cocaine-CPP in a time-dependent, nor-BNI-sensitive manner.

The study helps resolve an apparent contradiction between prior reports showing that kappa agonists suppress cocaine-CPP and our previous report that stress-induced activation of the DYN/kappa system potentiated cocaineCPP (McLaughlin et al, 2003). The results show that the key difference between the experimental protocols is in the timing of the cues, as stress releases DYN and activates the kappa receptors before the mice are given cocaine and placed in the conditioning chamber. Alternative explanations include; (1) the sites of drug action may be different from the sites of action of endogenously released kappa opioid, as pharmacologically administered drug distributes differently and achieves different concentrations in brain than does endogenous opioid peptide released by stress; (2) the response to kappa agonist may be different in a stressed mouse, as the actions of other neurohormones simultaneously released by stress may change the response to either kappa receptor activation or to cocaine; (3) repeated activation of the kappa systems by chronic stress may induce KOR desensitization that might result in different responses than acute drug injection; (4) prodynorphinderived opioids also act at non-kappa receptors (Chavkin and Goldstein, 1981; Young et al, 1986), and (5) the pharmacological actions of a selective kappa agonist may differ from those of endogenously released DYNs. Although these alternative explanations have not been excluded, the most parsimonious concept is that a kappa receptor activation by endogenous DYNs prior to cocaine conditioning produces a dysphoric state that enhances the rewarding properties of cocaine subsequently experienced by the animal. A presumptive dysphoric action of endogenous DYNs would be consistent with the dysphoric effects of kappa drugs administered to humans (Kumor et al, 1986; Pfeiffer et al, 1986) and the conditioned place aversion produced by kappa agonists in rodents (Shippenberg and Herz, 1986).

The novel demonstration in the present study that KOR gene disruption prevented FSS-induced increases in immobility, analgesia, and cocaine-CPP is consistent with previous observations. These results suggest that stress induces the release of the endogenous DYNs that activate the KOR to produce these behavioral effects (Mague et al, 2003; McLaughlin et al, 2003). Our findings are also consistent with a recent study demonstrating that repeated infusion of U50,488 produced a dose-dependent, nor-BNIsensitive leftward shift in the cocaine-choice dose-effect curve of rhesus monkeys self-administering cocaine but not food (Negus, 2004). The author speculates that chronic activation of kappa opioid systems, either from exogenous or endogenous sources, may enhance the relative reinforcing efficacy of cocaine, citing the ability of cocaine to attenuate both kappa agonist-induced decreases in mesolimbic dopamine levels (Maisonneuve et al, 1994; Thompson et al, 2000) and kappa agonist-induced place aversions (Suzuki et al, 1992). Antagonist effects of nor-BNI on cocaine reinforcement were also demonstrated in Wistar rats (Kuzmin et al, 1998).

Interpretation of knockout studies must be carried out cautiously as gene deletion can have other nonspecific effects (Tronche et al, 2002), and while disruption of the prodynorphin gene has been shown to prevent expression of the kappa-selective DYN peptides (Sharifi et al, 2001), expression of other prodynorphin-derived peptides is also blocked. The responsiveness of the kappa system was not grossly affected as prodynorphin gene deletion did not block the analgesic response to kappa agonists ( $\mathrm{Xu}$ et al, 2004). Thus, the consistency of results using nor-BNI, KOR gene deletion and prodynorphin gene deletion support the 
hypothesis that the potentiation of cocaine-CPP by FSS was caused by the release of endogenous DYNs that activated KORs. These results are also consistent with previous evidence that the DYN/kappa system contributes to the stress response (Basbaum and Fields, 1984; Millan and Herz, 1985; Przewlocki et al, 1987; Nabeshima et al, 1992).

The experimental results showing that a kappa agonist can substitute for stress-induced release of DYN suggests that kappa receptor activation is both necessary and sufficient; FSS was not required. Work remains to be done comparing the timing of KOR activation though FSS- or U50,488-exposure on a biochemical level, and correlating these results to the behavioral effects noted here, as has been demonstrated in previous studies of KOR phosphorylation and KOR agonist-induced tolerance (McLaughlin et al, 2004). However, the role of other mediators of the stress response was not excluded, and pharmacological activation of the kappa system by drug injection may also affect the HPA (Iyengar et al, 1986). Corticosterone has been implicated elsewhere as a mediator in stress-induced increases in drug self-administration (Piazza et al, 1990; Deroche-Gamonet et al, 2003; Shalev et al, 2003), although other studies have suggested this hormone is either not involved (Shaham et al, 1997; Lê et al, 2000) or only indirectly involved (Erb et al, 1998). Our results showed that treatments that blocked swim stress-induced potentiation of cocaine-CPP (ie nor-BNI pretreatment, KOR gene deletion, prodynorphin gene deletion) did not block swim stressinduced increases in serum corticosterone levels. However, endocrine methods (adrenalectomy with corticosterone replacement) were not utilized in this study to conclusively exclude a corticosterone involvement, limiting this conclusion. This may prove relevant, as a recent study by DerAvakian et al, (2005) demonstrated shock-induced potentiation of morphine CPP was not due to the shock-induced increase in corticosterone release, but rather an increase in the corticosterone response to morphine itself following prior shock exposure. Moreover, other evidence supports a role for CRF and other neurotransmitters in the regulation of the rewarding properties of addictive drugs (Piazza $e t$ al, 1990; see also Koob, 2003). The relationship between the stress response mediated by DYN and CRF-glucocorticoid modulation of cocaine reward as demonstrated previously (Yuferov et al, 2001; Deroche-Gamonet et al, 2003) requires further study.

The forced-swim test is an established and predictive animal model for the study of depression, with antidepressants typically reducing the duration of immobility exhibited (Porsolt et al, 1977; Lucki et al, 2001). Previous reports have shown that nor-BNI blocked the swim stressinduced immobility (Pliakas et al, 2001; Mague et al, 2003; McLaughlin et al, 2003) and suggested that kappa receptor antagonists may also be effective antidepressants by blocking endogenous DYN function. In addition, the reduction of immobility caused by the disruption of the KOR gene extends those previous findings, and further supports the suggestion that KOR-selective antagonists may provide a new therapeutic approach for the treatment of depression.

In conclusion, FSS-induced behaviors were shown to be sensitive to KOR gene disruption (this study), KOR antagonism and prodynorphin gene disruption (prior work). The present findings further extend earlier work by demonstrating that exogenous activation of the KOR was necessary and sufficient to mimic the measured effects of FSS in a time-dependent manner, thereby highlighting connections between the endogenous kappa opioid system and chronic stress, depression and drug abuse.

\section{ACKNOWLEDGEMENTS}

We thank Dr Uwe Hochgeschwender for generously providing the prodynorphin knockout mice. Joe Novak performed the mouse genotyping. The work was supported by USPHS Grants RO1 DA16898 and PO1-DA15916 (to CC) and RO3 Grants DA016656 and DA016415 (to JPM) from the National Institute on Drug Abuse.

\section{REFERENCES}

Basbaum AI, Fields HL (1984). Endogenous pain control systems: brainstem spinal pathways and endorphin circuitry. Annu Rev Neurosci 7: 309-338.

Chavkin C, Goldstein A (1981). Specific receptor for the opioid peptide dynorphin: structure-activity relationships. Proc Natl Acad Sci USA 78: 6543-6547.

Covington III HE, Miczek KA (2001). Repeated social-defeat stress, cocaine or morphine. Effects on behavioral sensitization and intravenous cocaine self-administration binges. Psychopharmacology 158: 388-398.

Der-Avakian A, Will MJ, Bland ST, Deak T, Nguyen KT, Schmid MJ et al (2005). Surgical and pharmacological suppression of glucocorticoids prevents the enhancement of morphine conditioned place preference by uncontrollable stress in rats. Psychopharmacology 179: 409-417.

Deroche-Gamonet V, Sillaber I, Aouizerate B, Izawa R, Jaber M, Ghozland S et al (2003). The glucocorticoid receptor as a potential target to reduce cocaine abuse. J Neurosci 23: $4785-4790$.

Erb S, Shaham Y, Stewart J (1998). The role of corticotropinreleasing factor and corticosterone in stress- and cocaineinduced relapse to cocaine seeking in rats. J Neurosci 18: 5529-5536.

Haile CN, GrandPre T, Kosten TA (2001). Chronic unpredictable stress, but not chronic predictable stress, enhances the sensitivity to the behavioral effects of cocaine in rats. Psychopharmacology 154: 213-220.

Hotchkiss AK, Pyter LM, Neigh GN, Nelson RJ (2004). Nycthemeral differences in response to restraint stress in CD-1 and C57BL/6 mice. Physiol Bev 80: 441-447.

Hough LB, Nalwalk JW, Chen Y, Schuller A, Zhu Y, Zhang J et al (2000). Improgan, a cimetidine analog, induces morphine-like antinociception in opioid receptor-knockout mice. Brain Res 880: 102-108.

Iyengar S, Kim HS, Wood PL (1986). Kappa opiate agonists modulate the hypothalamic-pituitary-adrenocortical axis in the rat. J Pharmacol Exp Ther 238: 429-436.

Koob GF (2003). Neuroadaptive mechanisms of addiction: studies on the extended amygdala. Eur Neuropsychopharmacol 13: 442-452.

Kumor KM, Haertzen CA, Johnson RE, Kocher T, Jasinski D (1986). Human psychopharmacology of ketocyclazocine as compared with cyclazocine, morphine and placebo. J Pharmacol Exp Ther 238: 960-968.

Kuzmin AV, Gerrits MAFM, Jan M, Van Ree JM (1998). Opioid receptor blockade with nor-binaltorphimine modulates cocaine self-administration in drug-naive rats. Eur J Pharmacol 358: 197-202. 
Lê AD, Harding S, Juzytsch W, Watchus J, Shalev U, Shaham Y (2000). The role of corticotrophin-releasing factor in stressinduced relapse to alcohol-seeking behavior in rats. Psychopharmacology 150: 317-324.

Lucki I, Dalvi A, Mayorga AJ (2001). Sensitivity to the effects of pharmacologically selective antidepressants in different strains of mice. Psychopharmacology 155: 315-322.

Mague SD, Pliakas AM, Todtenkopf MS, Tomasiewicz HC, Zhang Y, Stevens Jr WC et al (2003). Antidepressant-like effects of kappa-opioid receptor antagonists in the forced swim test in rats. J Pharmacol Exp Ther 305: 323-330.

Maisonneuve IM, Archer S, Glick SD (1994). U50,488, a kappa opioid receptor agonist, attenuates cocaine-induced increases in extracellular dopamine in the nucleus accumbens of rats. Neurosci Lett 181: 57-60.

McLaughlin JP, Marton-Popovici M, Chavkin C (2003). Kappa opioid receptor antagonism and prodynorphin gene disruption block stress-induced behavioral responses. J Neurosci 23: 5674-5683.

McLaughlin JP, Myers LC, Zarek PE, Caron MG, Lefkowitz RJ, Czyzyk TA et al (2004). Prolonged kappa-opioid receptor phosphorylation mediated by G-protein receptor kinase underlies sustained analgesic tolerance. J Biol Chem 279: 1810-1818.

Millan MJ, Herz A (1985). The endocrinology of the opioids. Int Rev Neurobiol 26: 1-83.

Nabeshima T, Katoh A, Wada M, Kameyama T (1992). Stressinduced changes in brain Met-enkephalin, Leu-enkephalin and dynorphin concentrations. Life Sci 51: 211-217.

Negus SS (2004). Effects of the kappa opioid agonist U50,488 and the kappa opioid antagonist nor-binaltorphimine on choice between cocaine and food in rhesus monkeys. Psychopharmacology (Berlin) 176: 204-213.

Pfeiffer A, Brantl V, Herz A, Emrich HM (1986). Psychotomimesis mediated by kappa opiate receptors. Science 233: 774-776.

Piazza PV, Deminiere JM, Le Moal M, Simon H (1990). Stress- and pharmacologically induced behavioral sensitization increases vulnerability to acquisition of amphetamine self-administration. Brain Res 514: 22-26.

Pliakas AM, Carlson RR, Neve RL, Konradi C, Nestler EJ, Carlezon Jr WA (2001). Altered responsiveness to cocaine and increased immobility in the forced swim test associated with elevated cAMP response element-binding protein expression in nucleus accumbens. J Neurosci 21: 7397-7403.

Porsolt RD, Le Pichon M, Jalfre M (1977). Depression: a new animal model sensitive to antidepressant treatments. Nature 266: 730-732.

Przewlocki R, Lason W, Hollt V, Silberring J, Herz A (1987). The influence of chronic stress on multiple opioid peptide systems in the rat: pronounced effects upon dynorphin in spinal cord. Brain Res 413: 213-219.

Shaham Y, Funk D, Erb S, Brown TJ, Walker C-D, Stewart J (1997). Corticotropin-releasing factor, but not corticosterone, is in- volved in stress-induced relapse to heroin-seeking in rats. J Neurosci 17: 2605-2614.

Shalev U, Marinelli M, Baumann MH, Piazza P-V, Shaham Y (2003). The role of corticosterone in food deprivation-induced reinstatement of cocaine seeking in the rat. Psychopharmacology 168: $170-176$.

Sharifi N, Diehl N, Yaswen L, Brennan MB, Hochgeschwender U (2001). Generation of dynorphin knockout mice. Brain Res Mol Brain Res 86: 70-75.

Shippenberg TS, Herz A (1986). Differential effects of mu and kappa opioid systems on motivational processes. NIDA Res Monogr 75: 563-566.

Suzuki T, Shiozaki Y, Masukawa Y, Misawa M, Nagase H (1992). The role of mu- and kappa-opioid receptors in cocaine-induced conditioned place preference. Jpn J Pharmacol 58: 435-442.

Terman GW, Jin W, Cheong YP, Lowe J, Caron MG, Lefkowitz RJ et al (2004). G-protein receptor kinase 3 (GRK3) influences opioid analgesic tolerance but not opioid withdrawal. $\mathrm{Br} J$ Pharmacol 141: 55-64.

Thompson AC, Zapata A, Justice Jr JB, Vaughan RA, Sharpe LG, Shippenberg TS (2000). Kappa-opioid receptor activation modifies dopamine uptake in the nucleus accumbens and opposes the effects of cocaine. J Neurosci 20: 9333-9340.

Tronche F, Casanova E, Turiault M, Sahly I, Kellendonk C (2002). When reverse genetics meets physiology: the use of site-specific recombinases in mice. FEBS Lett 529: 116-121.

Vaught JL, Takemori AE (1979). Differential effects of leucine and methionine enkephalin on morphine-induced analgesia, acute tolerance and dependence. J Pharmacol Exp Ther 208: 86-90.

Will MJ, Watkins LR, Maier SF (1998). Uncontrollable stress potentiates morphine's rewarding properties. Pharmacol Biochem Behav 60: 655-664.

$\mathrm{Xu}$ M, Petraschka M, McLaughlin JP, Westenbroek RE, Caron MG, Lefkowitz RJ et al (2004). Neuropathic pain activates the endogenous kappa opioid system in mouse spinal cord and induces opioid receptor tolerance. $J$ Neurosci 24: 4576-4584.

Young EA, Walker JM, Lewis ME, Houghten RA, Woods JH, Akil H (1986). $\left[{ }^{3} \mathrm{H}\right]$ dynorphin A binding and kappa selectivity of proDYN peptides in rat, guinea-pig and monkey brain. Eur $J$ Pharmacol 121: 355-365.

Yuferov V, Zhou Y, LaForge KS, Spangler R, Ho A, Kreek MJ (2001). Elevation of guinea pig brain preprodynorphin mRNA expression and hypothalamic-pituitary-adrenal axis activity by 'binge' pattern cocaine administration. Brain Res Bull 55: 65-70.

Zhang Y, Butelman ER, Schlussman SD, Ho A, Kreek MJ (2004). Effect of the kappa opioid agonist R-84760 on cocaine-induced increases in striatal dopamine levels and cocaine-induced place preference in C57BL/6J mice. Psychopharmacology (Berlin) 173: $146-152$. 